\title{
Efektivitas Layanan Bimbingan Belajar dalam Membantu Kegiatan Pembelajaran Daring dari Sekolah
}

\author{
Rian Sugianto \\ Universitas Sebelas Maret \\ riansugianto@gmail.com
}

\section{Article History}

received 3/12/2020

\begin{abstract}
The implementation of learning activities in schools has undergone a very big change with the covid-19 pandemic in Indonesia, learning activities that were initially carried out face-to-face in schools were replaced with online learning or commonly known as online learning. This change certainly has a serious impact on the systems and techniques of implementing educational activities in Indonesia, especially in school learning activities. The pros and cons of course become a natural thing when there is a change in policy. Online learning is not only technically problematic, but the essence or purpose of learning has not really been tested for its effectiveness in the online learning system. This study uses descriptive qualitative research that describes tutoring services in reducing students' learning difficulties during the COVID-19 pandemic. The results showed that the barriers to online learning were parents of ignorant students, internet access, difficulty understanding the material, feeling lazy and having difficulty concentrating. The solutions are: making online learning media systems, communicating with parents, making learning summaries, giving assignments that encourage students to be active.
\end{abstract}

Keywords: tutoring, online learning, elementary school

\begin{abstract}
Abstrak
Pelaksanaan Kegiatan Pembelajaran di Sekolah mengalami perubahan yang sangat besar dengan adanya pandemi covid-19 di Indonesia, kegiatan pembelajaran yang awalnya dilakukan dengan tatap muka langsung di sekolah digantikan menjadi pembelajaran dalam jaringan atau biasa dikenal dengan istilah pembelajaran Daring. Perubahan ini tentunya membawa dampak serius dalam sistem dan teknik pelaksanaan kegiatan penddikan di Indonesia, khususnya dalam kegiatan pembelajaran sekolah. Pro dan Kontra tentunya menjadi hal ynag wajar ketika ada suatu perubahan kebijakan. Pembelajaran daring tidak hanya bermasalah dalam teknis saja, akan tetapi esensi ataupun tujuan pembelajaran belum betul-betul teruji keefektifannya dalam dalam sistem pembelajaran daring. Penelitian ini menggunakan penelitian kualitatif deskriptif yang mendeskripsikan layanan bimbingan belajar dalam mengurangi kesulitan belajar peserta didik pada masa pandemi COVID-19. Hasil penelitian menunjukan bahwa hambatan pembelajaran daring yaitu orang tua peserta didik gaptek, akses internet, sulit memahami materi, rasa malas dan sulit berkonsentrasi. Solusinya yaitu: membuat media pembelajaran sistem daring, komunikasi dengan wali murid, membuat ringkasan pembelajaran, memberikan tugas yang mendorong peserta didik untuk aktif.
\end{abstract}

Kata kunci: bimbingan belajar, pembelajaran daring, sekolah dasar

Social, Humanities, and Education Studies (SHEs): Conference Series https://jurnal.uns.ac.id/shes

p-ISSN 2620-9284

e-ISSN 2620-9292 


\section{PENDAHULUAN}

Pendidikan merupakan sarana untuk manusia dalam mengembangkan potensi yang dimiliki. Proses pendidikan adalah mempersiapkan seseorang untuk hidup layak di masa depan melalaui pengajaran dan pelatihan. Berkaitan dengan proses belajar, Rusmiati (2017: 23) mengatakan bahwa belajar merupakan bukan suatu hasil atau tujuan melainkan suatu proses atau kegiatan. Sehingga belajar merupakan suatu proses untuk mencapai hasil belajar yang terlihat setelah pembelajaran berakhir. Hasil belajar adalah pencapaian bentuk perubahan perilaku atau kemampuan baik dari aspek kognitif, aspek afektif, dan aspek psikomotoris pada siswa yang didapat melalui proses belajar.

Virus Corona yang merebak masuk ke Indonesia sejak bulan maret 2020 menjadi awal dari perubahan tatanan kehidupan dunia khususnya Indonesia. Seperti halnya wabah virus MERS dan SARS, Covid-19 tergolong menjadi virus yang berbahaya karena dengan mudah menular kepada orang lain dan dapat berakibat fatal. Oleh karena itu pemerintah mengeluarkan aturan untuk melindungi masyarakat dari Covid19. Pandemi Covid-19 berpengaruh besar terhadap kehidupan masyarakat, termasuk dalam hal pendidikan.

Pada awal masuknya Covid-19 pemerintah meliburkan sekolah selama 2 minggu untuk mencegah penularan covid-19 yang semakin menambah. Karena penanganan yang belum dapat optimal dan penderita terus bertambah maka pemerintah memutuskan untuk melanjutkan libur dengan belajar dirumah. Pendidik harus memastikan kegiatan belajar mengajar tetap berjalan, meskipun peserta didik berada di rumah. Pendidik dituntut mendesain media pembelajaran sebagai inovasi dengan memanfaatkan media daring (online). Hal Ini juga ditegaskan oleh pemerintah dengan dikeluarkannya surat edaran Menteri Pendidikan dan Kebudayaan Republik Indonesia terkait Surat Edaran Nomor 4 Tahun 2020 tentang Pelaksanaan Kebijakan Pendidikan dalam Masa Darurat Penyebaran Corona Virus Disease (Covid-19).

Menteri Pendidikan dan Kebudayaan (Mendikbud) Nadiem Makarim memutuskan, seluruh proses pembelajaran anak usia sekolah dilakukan melalui pembelajaran jarak jauh (PJJ) atau daring selama masa darurat Covid-19. Memang tidak semua anak dapat menjalani secara konsisten pembelajaran daring karena berbagai keterbatasan. Misalnya, ketiadaan fasilitas gawai (ponsel, laptop, dan tablet), rendahnya pemahaman tentang media digital, terbatasnya kemampuan membeli pulsa, dan keterbatasan sinyal. Namun, hampir sebagian besar peserta didik telah merasakan pembelajaran daring. Pembelajaran daring tidak hanya bermasalah dalam teknis saja, akan tetapi esensi ataupun tujuan pembelajaran belum betul-betul teruji keefektifannya dalam sistem pembelajaran daring. Masalah-masalah baru mulai bermunculan ditengah permasalahan teknis belum terselesaikan dengan baik. Peserta didik yang terbiasa belajar secara tatap muka dan dijelaskan langsung dengan guru, kini guru hanya memberi instruksi bacaan dan memberi tugas, hal tersebut tentunya membuat peserta didik semakin kebingungan karena tidak adanya penjelasan yang jelas akan tetapi dipaksa untuk paham dengan mengerjakan tugas. Banyaknya mata pelajaran yang ditempuh peserta didik, sama dengan banyaknya tugas yang akan peserta didik selesaikan. Dengan banyaknya tugas tersebut membuat peserta didik tertekan secara psikologis.

Peserta didik membutuhkan bimbingan dalam memahami materi terlebih peserta didik yang masih dalam membentuk pemikiran seperti tingkat PAUD hingga SD. Anak dalam usia-usia itu sedang mengeksplorasi kehidupan, jadi apa bila tidak terdapat pengarahan maksud dari materi yang sedang dipelajari memungkinkan peserta didik akan lebih bingung atau salah memahami materi. Bimbingan belajar yang dapat 
dilaksanakan di rumah-rumah warga dengan tetap memahami protokol kesehatan akan lebih membantu peserta didik dalam pemahaman materi dan pengerjaan tugas.

\section{METODE}

Berdasarkan tujuan dan masalah yang diteliti, penelitian ini termasuk penelitian deskriptif kualitatif. Adapun yang dimaksud dengan penelitian kualitatif yaitu penelitian yang bermaksud untuk memahami fenomena tentang apa yang dialami oleh subjek penelitian secara holistik, dan dengan cara deskripsi dalam bentuk kata-kata dan bahasa, pada suatu konteks khusus yang alamiah dan dengan memanfaatkan berbagai metode ilmiah. Penelitian deskriptif termasuk salah satu jenis penelitian kualitatif. Penelitian ini bertujuan untuk mengangkat fakta, keadaan, variabel dan fenomena-fenomena yang terjadi ketika penelitian berlangsung dan menyajikan apa adanya. Alasan peneliti menggunakan penelitian kualitatif karena dalam penelitian ini banyak hal yang belum dipahami sehingga membutuhkan pengkajian secara mendalam, dan masalah yang timbul sangat kompleks, dan peneliti juga bermaksud untuk memahami situasi sosial secara mendalam.

Penelitian deskriptif menuturkan dan menafsirkan data yang berkenaan dengan situasi yang terjadi, sikap dan pandangan yang menggejala di masyarakat, hubungan antara variabel, bertentangan dua kondisi atau lebih, pengaruh terhadap suatu kondisi, perbedaan antara fakta. Pada umumnya kegiatan penelitian deskriptif meliputi pengumpulan data, analisis data, interpretasi data, serta diakhiri dengan kesimpulan yang didasarkan pada penganalisisan data tersebut. Penelitian ini mendeskripsikan layanan bimbingan belajar dalam mengurangi kesulitan belajar peserta didik pada masa COVID-19. Solusi tersebut diberikan kepada peserta didik dan kemudian dilihat layanan bimbingan belajar dalam mengurangi kesulitan belajar peserta didik kemudian diambil beberapa peserta didik untuk diwawancarai mengenai strategi guru dalam pembelajaran.

\section{HASIL DAN PEMBAHASAN}

\section{Dampak covid-19 dalam kegiatan sekolah}

Proses pembelajaran di sekolah merupakan alat kebijakan publik terbaik sebagai upaya peningkatan pengetahuan dan skill. Selain itu banyak peserta didik menganggap bahwa sekolah adalah kegiatan yang sangat menyenangkan, mereka bisa berinteraksi satu sama lain. Sekolah dapat meningkatkan keterampilan sosial dan kesadaran peserta didik. Sekolah secara keseluruhan adalah media interaksi antar peserta didik dan guru untuk meningkatkan kemampuan inteligensi, skill, rasa tanggung jawab dan kasih sayang diantara mereka. Tetapi sekarang kegiatan yang bernama sekolah berhenti dengan tiba-tiba karena gangguan Covid-19.

Ada dua dampak bagi kegiatan pembelajaran di sekolah yang disebabkan oleh pandemi Covid-19. Pertama adalah dampak jangka pendek, yang dirasakan oleh keluarga peserta didik. Demikian juga dengan problem psikologis peserta didik yang terbiasa belajar bertatap muka langsung dengan guru mereka.

Seluruh kegiatan sekolah berubah karena covid-19. Pelaksanaan pembelajaran dilakukan secara online. Proses ini berjalan pada skala yang belum pernah terukur dan teruji sebab belum pernah terjadi sebelumnya. Hal ini tentunya membuat semua pihak serba kebingungan, sebab infrastruktur informasi teknologi sangat terbatas. Penilaian peserta didik bergerak online dan banyak trial and error dengan sistem yang tidak ada kepastian. Kedua adalah dampak jangka panjang. Banyak kelompok masyarakat umumnya di Indonesia akan terpapar dampak jangka panjang dari covid19 ini. Dampak kegiatan pembelajaran dalam waktu jangka panjang adalah aspek 
keadilan dan peningkatan ketidaksetaraan kelompok masyarakat dan antar daerah di Indonesia.

\section{Study from home (Belajar dari rumah )}

Di tengah kondisi penyebaran Pandemi COVID-19 (corona virus disease) yang melanda Indonesia, dunia pendidikan pun terkena imbas dari bencana ini. Beberapa daerah telah mulai melakukan proteksi terhadap seluruh warga termasuk para peserta didik dengan menerapkan study from home.. Dengan kebijakan study from home ini, seluruh elemen ekosistem pendidikan harus beradaptasi dengan metode pembelajaran jarak jauh. Bagi sekolah-sekolah yang telah memiliki aplikasi pendidikan, tentunya proses adaptasi akan jauh lebih mudah dalam proses pembelajaran jarak jauh ini dengan memanfaatkan teknologi aplikasi. Sementara bagi sekolah yang belum memiliki solusi aplikasi serupa, tentunya proses pembelajaran jarak jauh dengan study from home akan sedikit mengalami kendala (Putria, 2020).

Pemerintah Indonesia juga telah mengambil tindakan sejak Indonesia terkonfirmasi kasus COVID-19 pertama pada awal Maret 2020. Pemerintah Indonesia

menghimbau agar mengurangi kegiatan berkumpul dan melakukan kegiatannya di rumah guna mencegah penyebaran COVID-19. Kegiatan yang dimaksud adalah bekerja, beribadah, dan juga bersekolah. Jadi kegiatan-kegiatan itu dilakukan dari rumah secara daring. Namun, banyak masyarakat Indonesia yang menganggap remeh himbauan pemerintah ini dan menyebabkan kenaikkan pasien yang terindikasi COVID-19, pemerintah mulai mengeluarkan tindakan baru, yaitu PSBB (Pembatasan Sosial Berskala Besar) dan memperpanjang waktu pelajar agar tetap belajar di rumah dengan metode daring. Bersekolah ataupun berkuliah di rumah (Study From Home) melalui metode pembelajaran daring dengan menggunakan aplikasi, seperti Google Classroom, WhatsApp, Google Meet, Zoom, dan lain-lain, yang bisa diakses menggunakan smartphone, tablet, notebook atau laptop yang telah terkoneksi internet (Yanti, 2020).

Dalam rangka pemenuhan hak peserta didik untuk mendapatkan layanan pendidikan selama darurat penyebaran Corona Virus Disease (COVID- 19) melalui penyelenggaraan kegiatan belajar dari rumah sebagaimana tercantum dalam Surat Edaran Nomor 4 Tahun $2 \mathrm{O} 2 \mathrm{O}$ tentang Pelaksanaan Kebijakan Pendidikan dalam Masa Darurat berikut:

Penyebaran Corona Virus Disease (COVID-19), disampaikan hal-hal sebagai

1. Belajar dari Rumah selama darurat penyebaran Corona Virus Disease (COVID19) dilaksanakan dengan tetap memperhatikan protokol penanganan COVID19; Tujuan Pelaksanaan Belajar Dari Rumah Pelaksanaan Belajar Dari Rumah (BDR) selama darurat COVID-19 bertujuan untuk: memastikan pemenuhan hak peserta didik untuk mendapatkan layanan pendidikan selama darurat COVID19, melindungi warga satuan pendidikan dari dampak buruk COVID-19, mencegah penyebaran dan penularan COVID-19 di satuan pendidikan; dan memastikan pemenuhan dukungan psikososial bagi pendidik, peserta didik dan orang tua/wali.

2. Prinsip Pelaksanaan Belajar Dari Rumah BDR dilaksanakan sesuai dengan prinsip- prinsip yang tertuang dalam Surat Edaran Menteri Pendidikan dan Kebudayaan Nomor 4 Tahun 2020 tentang Pelaksanaan Kebijakan Pendidikan dalam Masa Darurat Penyebaran Corona Virus Disease (COVID 19), yaitu: keselamatan dan kesehatan lahir batin peserta didik, pendidik, kepala satuan pendidikan dan seluruh warga satuan pendidikan menjadi pertimbangan utama dalam pelaksanaan BDR, kegiatan BDR dilaksanakan untuk memberikan 
pengalaman belajar yang bermakna bagi peserta didik, tanpa terbebani tuntutan menuntaskan seluruh capaian kurikulum, BDR dapat difokuskan pada pendidikan kecakapan hidup, antara lain mengenai pandemi COVID-19, dan materi pembelajaran bersifat inklusif sesuai dengan usia dan jenjang pendidikan, konteks budaya, karakter dan jenis kekhususan peserta didik, aktivitas dan penugasan selama BDR dapat bervariasi antar daerah, satuan pendidikan dan Peserta Didik sesuai minat dan kondisi masing masing, termasuk mempertimbangkan kesenjangan akses terhadap fasilitas BDR, hasil belajar peserta didik selama BDR diberi umpan balik yang bersifat kualitatif dan berguna dari guru tanpa diharuskan memberi skor/nilai kuantitatif, dan mengedepankan pola interaksi dan komunikasi yang positif antara guru dengan orang tua/wali.

Media dan Sumber Belajar Pembelajaran Luring Pembelajaran di rumah secara luring dalam masa BDR dapat dilaksanakan melalui: televisi, contohnya Program Belajar dari Rumah melalui TVRI, radio; modul belajar mandiri dan lembar kerja, dan bahan ajar cetak, alat peraga dan media belajar dari benda dan lingkungan sekitar. Yang jadi pembahasannya disini adalah, efektifkah, Study From Home sebagai metode pembelajaran untuk peserta didik pada masa pandemi ini? Karena tidak semua peserta didik mempunyai smartphone untuk mengakses aplikasi pembelajaran tersebut. Bahkan di lbu kota sendiripun, yang bisa dikatakan lebih maju dibanding daerah-daerah lain di Indonesia belum tentu semuanya mempunyai smartphone. Selain smatphone, sinyal dan paket data juga merupakan hal yang tidak kalah penting. Karena percuma jika peserta didik mempunyai smartphone tetapi tidak diimbangi oleh adanya paket data dan sinyal yang bagus. Permasalahan lainnya adalah, kuota data yang cepat habis. Study From Home membuat kita menggunakan kuota lebih banyak dibandingkan pemakaian di hari-hari biasanya. Prinsip Kegiatan Belajar Mengajar (KBM) adalah saat satuan pendidikan kembali beroperasi wajib memastikan terpenuhinya tujuan pendidikan di masa pandemi COVID-19, yaitu: memastikan pemenuhan hak anak untuk mendapatkan akses pendidikan yang berkualitas, melindungi seluruh warga satuan pendidikan, dan mencegah penyebaran dan penularan COVID-19 di lingkungan satuan pendidikan.

\section{Sistem belajar dari rumah}

Dalam surat edaran nomor 15 tahun 2020 tentang pedoman penyelenggaraan belajar dari rumah dalam masa darurat penyebaran corona virus disease (covid-19) dalam bab 2 poin $\mathrm{C}$ yang berbunyi pelaksanaan belajar dari rumah oleh guru. Dalam poin tersebut dijelaskan bahwa guru harus memfasislitasi pelaksanaan pjj (pembelajaran jarak jauh) secara daring maupun luring. Dalam proses pembelajaran daring atau jarak jauh terdiri atas tatap muka secara virtual tujuannya untuk memastikan adanya interaksi secara langsung antara guru dengan peserta didik. Dalam pembelajaran tatap muka secara virtual dijelaskan bahwa dalam kegiatan pembukaan pembelajaran secara tatap muka virtual hendaknya guru mengecek kehadiran peserta didiknya, agar mengetahui kondisi peserta didik dirumah saat ini, apakah sehat atau kurang sehat, sehingga guru dapat memantau peserta didik dengan baik, guru mengajak peserta didik untuk berdoa'a sebelum dan sesudah pembelajaran.

a. Pemberian Materi

Kemendikbud mengimbau untuk para pendidik dapat menghadirkan belajar yang menyenangkan dari rumah bagi peserta didik. Setelah peneliti mewawancari peserta didik dalam progam pendampingan belajar tentang bagaimana sikap anda ketika pembelajaran jarak jauh? Peserta didik mengungkapkan bahwa pembelajaran jarak 
jauh tidak menyenangkan dan merasa keberatan. Peneliti menyimpulkan bahwa proses pembelajaran peserta didik secara daring bagi peserta didik kurang menyenangkan. Dalam grup whatsapp guru tidak pernah menyampaikan materi apapun, guru hanya memberikan tugas yang ada di buku tema. Padahal kemendikbud sudah menyiapkan media untuk belajar peserta didik dari rumah melalui progam belajar tvri, didalam progam tersebut kemendikbud sudah mengemas semua materi mulai dari jenjang PAUD, SD, SMP, SMA dan itupun dalam waktu yang berbeda, sehingga dalam pembelajaran melalui siaran TVRI peserta didik akan lebih mudah untuk memahami suatu materi. Setiap sekolah memiliki kebijakan masing-masing. Di SD domisili peneliti, guru meminta peserta didiknya untuk belajar melalui siaran tvri, akan tetapi lebih banyak peserta didik mengabaikannya, ternyata lebih praktis belajar menggunakan buku tematik. Padahal materi- materi yang ada dibuku tematik kurang lengkap, sehingga peserta didik merasa kebingungan pada saat mendapatkan tugas dari guru.

\section{b. Penugasan}

Pesan dari Mendikbud Nadiem usai rapat via teleconverence dengan presiden jokowi dan mentri yang terkait di Jakarta " kami juga ingin menekankan bahwa walaupun banyak sekolah melakukan belajar dari rumah, bukan berarti gurunya hanya memberikan tugas saja kepada murid, akan tetapi juga harus ikut berinteraksi dan berkomunikasi membantu muridnya dalam mengerjakan tugas. Peneliti telah melihat proses pembelajarn melalui via whatsapp group guru hanya memberikan arahan tentang tugas hari tersebut, dan tidak dijelaskan, walaupun tugasnya sedikit peserta didik sd masih kesulitan untuk menyelesikan tugas tersebut. Dalam program kerja pendampingan belajar anak, anak merasa agak lebih tenang dan dapat menyelesaikan tugas dengan baik, karena peneliti menjelaskan dan mengajari bagaimana menyelesaikan tugas yang sudah ada. Peneliti menemukan persoalan tugas dari anak pendampingan belajar tentang penjumlahan ribuan, peneliti menjelaskan atau memberi solusi untuk lebih mudah dalam menghitung dalam jumlah ribuan dengan cara penjumlahan bersusun, Setelah dijelaskan secara terperinci anak tersebut memahaminya dengan baik. Setelah anak menyelesaikan tugas guru meminta tugas dikumpulkan hari sabtu dan tidak ada umpan balik, guru hanya meminta tugastugas dari anak-anak.

\section{c. Penilaian}

Penilaian menurut permendikbud nomor 23 tahun 2016 tentang penilaian hasil belajar memuat 3 aspek yaitu, sikap, pengetahuan dan ketrampilan. Ketiga aspek penilaian inilah yang nantinya dijadikan sebagai laporan akhir penilaian guru terhadap hasil belajar peserta didik. Menurut peneliti penilaian guru pada masa covid-19 dan masih belajar dari rumah dapat menilai dengan memberikan tugas keseharian peserta didik yang meliputi nilai karakter mulai dari religious, nasionalis, integritas, gotong royong dan kemandirian. Dalam melaksanakn tugas 5 nialai karakter dapat dijadikan sebagai penilaian sikap dan ketrampilan. Akan tetapi dalam pembelajaran jarak jauh dalam tingkatan SD tidak menerapkan itu, jadi penilaian berdasarkan tugas terstruktur setiap hari.

\section{Hambatan dan solusi}

a. Hambatan

1) Orang tua peserta didik Gaptek

Untuk daerah perkotaan sistem online lebih mudah diterapkan dibandingkan di pedesaan, karena sebagian besar sudah mengenal teknologi. Berbeda halnya dengan orang pedesaan yang masih awam dengan teknologi dan tidak semua orang memiliki 
Hp yang canggih. Sehingga, pembelajaran secara online di rasa memberatkan peserta didik maupun orang tua peserta didik.

2) Akses Internet

Akses internet merupakan salah satu kendala yang cukup banyak dialami bagi para peserta didik dan orang tua peserta didik ketika melakukan pembelajaran secara online. Salah satu faktornya adalah ketersediaan sinyal yang kurang bagus di berbagai daerah, terlebih bagi peserta didik yang berada di daerah pedalaman yang masih susah sinyal. Maka peserta didik harus mengeluarkan uang lebih untuk membeli kuota internet. Pembelian kuota internet memiliki kendala apabila orang tua dari peserta didik tersebut sedang kesusahan, sehingga peserta didik kesulitan juga untuk membeli kuota internet. Proses untuk mengikuti pembelajaran secara online pun menjadi terkendala dan peserta didik menjadi tidak bisa fokus mengikuti pembelajaran jika sinyal terganggu akibat cuaca buruk dan lain sebagainya (Anugrahana, 2020).

3) Sulit Memahami Materi

Akibat akses internet yang mengalami gangguan, maka proses pembelajaran pun menjadi terganggu, sehingga pemahaman peserta didik terhadap materi pun mengalami kesulitan. Jika peserta didik ketika belajar secara tatap muka langsung saja masih belum paham, apalagi jika belajar yang dilakukan dengan sistem online. Maka dari itu, peserta didik harus inisiatif belajar mandiri dan juga mencari sumber-sumber lain di internet untuk menambah pemahaman terhadap materi yang diajarkan (Rigianti, 2020).

4) Rasa Malas dan Sulit Berkonsentrasi

Belajar secara online justru malah menambah rasa malas dan juga sulit untuk berkonsentrasi bagi peserta didik. Selain karena sudah pusing dengan tugas-tugas yang diberikan, peserta didik juga menjadi lebih banyak waktu untuk bermain gawai. Seperti game, membuka youtube, dan sosial media lainnya dibandingkan dengan belajar. Akibatnya muncul rasa malas yang sangat susah untuk dilawan dan juga sulitnya berkonsentrasi ketika belajar, terlebih ketika guru malah sering memberikan banyak tugas yang malah akan membuat peserta didik semakin bosan dan stress ketika belajar (Rigianti, 2020).

b. Solusi :

1) Membuat media pembelajaran sistem daring.

Media yang dibuat tidak hanya dengan menggunakan video, tetapi juga dengan media yang dapat diberikan kepada peserta didik yang orang tuanya tidak memiliki HP yang canggih. Misalnya seperti yang dilakukan salah satu Guru yaitu dengan membuat video pembelajaran dan memberikan modul kepada peserta didik (Dewi, 2020).

2) Komunikasi dengan wali murid.

Komunikasi dengan orang tua peserta didik sangat penting dalam masa pandemi seperti. Komunikasi dengan orang tua peserta didik dapat dilakukan dengan mengadakan sosialisasi kepada orang tua peserta didik, tentu saja sosialisasi dilakukan dengan mematuhi protokol kesehatan. Sosialisasi berisi mengenai peran orang tua dalam membantu anak belajar online.

3) Membuat Ringkasan Pembelajaran

Ringkasan pembelajaran yang berupa inti materi sangat diperlukan peserta didik dalam memahami pembelajaran. Sehingga, guru dapat memberikan ringkasanringkasan materi kepada peserta didik dari berbagai sumber.

4) Memberikan tugas yang mendorong peserta didik untuk aktif. 
Sebagian besar orang tua peserta didik mengeluh mengenai tugas yang diberikan oleh guru terlalu banyak, maka dari itu guru wajib mempertimbangkan porsi tuugas yang diberikan. Selain itu guru juga dapat memberikan tugas yang merangsang peserta didik untuk aktif.

\section{SIMPULAN}

Ada dua dampak bagi keberlangsungan pendidikan yang disebabkan oleh pandemi Covid-19. Pertama adalah dampak jangka pendek, yang dirasakan oleh banyak keluarga di Indonesia baik di kota maupun di desa.

Pandemi COVID-19 (corona virus disease) yang melanda Indonesia, dunia pendidikan pun terkena imbas dari bencana ini. Beberapa daerah telah mulai melakukan dari rumah dalam masa darurat penyebaran corona virus disease (covid19) proteksi terhadap seluruh warga termasuk Permendikbud Nomor 23 Tahun 2016 Tentang para peserta didik dengan menerapkan study from home.

Sistem belajar dari rumah, dalam surat edaran nomor 15 tahun 2020 tentang pedoman penyelenggaraan belajar dari rumah dalam masa darurat penyebaran corona virus disease (covid-19) dalam bab 2 poin $C$ yang berbunyi pelaksanaan belajar dari rumah oleh guru.

Hambatan : orang tua peserta didik gaptek, akses internet, sulit memahami materi, rasa malas dan sulit berkonsentrasi. Solusinya yaitu : membuat media pembelajaran sistem daring, komunikasi dengan wali murid, membuat ringkasan pembelajaran, memberikan tugas yang mendorong peserta didik untuk aktif.

\section{DAFTAR PUSTAKA}

Aji, Rizqon Halal Syah. (2020). Dampak Covid-19 pada Pendidikan di Indonesia: Sekolah, Keterampilan, dan Proses Pembelajaran. Jurnal Sosial \& Budaya Syar-i FSH UIN Syarif Hidayatullah Jakarta Vol. 7 No. 5. Halaman 395-402,

Nelyahardi, Molia Prizunil. (2016). Layanan Bimbingan Belajar dalam Mengurangi Kesulitan Belajar Peserta didik Kelas IV Sekolah Dasar. Jurnal Gentala Pendidikan Dasar. Vol.1 No. I. Halaman 117-13. http://onlinejournal.unja.ac.id/index.php/gentala

Surat edaran kemendikbud No 15 Tahun 2020 tentang pedoman penyelenggaraan belajar Penilaian Hasil Belajar.

Dewi, W. A. F. (2020). Dampak Covid-19 terhadap implementasi pembelajaran daring di Sekolah Dasar. Edukatif: Jurnal IImu Pendidikan, 2(1), 55-61

Rigianti, H. A. (2020). Kendala Pembelajaran Daring Guru Sekolah Dasar Di Banjarnegara. Elementary School: Jurnal Pendidikan dan Pembelajaran ke-SDan, $7(2)$.

Yanti, M. T., Kuntarto, E., \& Kurniawan, A. R. (2020). Pemanfaatan Portal Rumah Belajar Kemendikbud Sebagai Model Pembelajaran Daring di Sekolah Dasar. Adi Widya: Jurnal Pendidikan Dasar, 5(1), 61-68.

Putria, H., Maula, L. H., \& Uswatun, D. A. (2020). Analisis proses pembelajaran dalam jaringan (daring) masa pandemi covid-19 pada guru sekolah dasar. Jurnal Basicedu, 4(4), 861-870.

Anugrahana, A. (2020). Hambatan, solusi dan harapan: pembelajaran daring selama masa pandemi covid-19 oleh guru sekolah dasar. Scholaria: Jurnal Pendidikan dan Kebudayaan, 10(3), 282-289. 